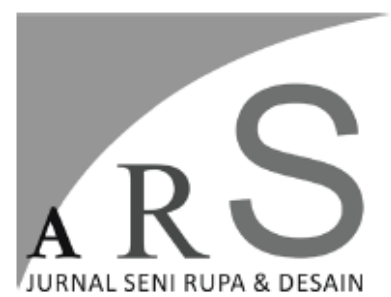

Volume 21 Nomor 1 April 2018

\section{TATA KELOLA RUANG MUSEUM SONOBUDOYO DAN RUANG MUSEUM RADYA PUSTAKA : SEBUAH PERBANDINGAN}

\author{
Sumartono \\ Jurusan Desain, Fakultas Seni Rupa, Institut Seni Indonesia Yogyakarta \\ E-mail: tono2maret@yahoo.co.id
}

\begin{abstract}
ABSTRAK
Setelah terjadinya beberapa kali pencurian beberapa benda bersejarah, terutama di Museum Radya Pustaka, ada upaya di pihak pengelola Museum Sonobudoyo dan Museum Radya Pustaka untuk menata kembali pengelolaan ruang di kedua museum tersebut. Hal inilah menarik untuk diteliti dan dibandingkan. Penelitian ini dilakukan untuk menjawab dua masalah: (1) Aspek-aspek apa yang digarap dalam proses tata kelola ruang Museum Sonobudoyo Yogyakarta dan ruang Museum Radya Pustaka Surakarta?, (2) Apa persamaan dan perbedaan proses tata kelola ruang Museum Sonobudoyo Yogyakarta dan Museum Radya Pustaka Surakarta? Metode penelitian yang digunakan dalam penelitian ini adalah metode komparatif. Metode komparatif bertujuan membandingkan dua subjek penelitian dalam rangka memperlihatkan persamaan dan perbedaan di antara keduanya. Hasil penelitian memperlihatkan bahwa dari perspektif tata kelola ruang, kedua museum masih menghadapi banyak kendala, meskipun secara keseluruhan tata kelola ruang pada Museum Sonobudoyo masih lebih baik daripada tata kelola Museum Radya Pustaka.
\end{abstract}

Kata kunci: tata kelola, Museum Sonobudoyo, Museum Radya Pustaka, komparasi

\title{
ABSTRACT
}

After the theft of several historic objects several times, especially in the Radya Pustaka Museum, there was an effort on the part of the manager of the Yogyakarta Sonobudoyo Museum and the Surakarta Radya Pustaka Museum to restructure the management of space in the two museums. This is interesting to study and compare. This research was conducted to answer two problems: (1) What aspects were worked out in the spatial management process of the Sonobudoyo Museum and the Radya Pustaka Surakarta Museum?, (2) What are the similarities and differences in the spatial management process of the Sonobudoyo Museum and the Radya Museum Surakarta? The research method used in this study is the comparative one. The comparative method aims to compare the two research subjects in order 
to show similarities and differences between the two. The results show that from the perspective of spatial management, the two museums still face many obstacles, although the overall spatial management of the Sonobudoyo Museum is still better than that of the Radya Pustaka Museum.

Keywords: management, Sonobudoyo Museum, Radya Pustaka Museum, comparison

\section{Pendahuluan}

Museum Sonobudoyo di Yogyakarta dan Museum Radya Pustaka di Surakarta adalah dua museum penting yang erat kaitannya dengan keberadaan dan perkembangan historis Keraton (Kerajaan) Yogyakarta dan Keraton Surakarta. Berbagai benda koleksi berupa naskah-naskah kuno dan benda-benda seni rupa tersimpan di berbagai ruang pada kedua museum tersebut. Meskipun selama ini telah dilakukan pengamanan benda-benda koleksi pada kedua museum tersebut, beberapa kali sejumlah benda berharga koleksi kedua museum tersebut telah dicuri orang. Meskipun jumlah pencurian benda berharga tersebut lebih seing terjadi di Museum Radya Pustaka Surakarta, kasus pencurian yang sering terjadi di kedua museum tersebut betul-betul memprihatinkan. Setelah terjadinya beberapa kali pencurian beberapa benda bersejarah, terutama di Museum Radya Pustaka, ada upaya di pihak pengelola Museum Sonobudoyo dan Museum Radya Pustaka untuk menata kembali pengelolaan ruang di kedua museum tersebut. Hal inilah yang menarik untuk diteliti.

Penelitian ini penting karena realitas kedua museum tersebut berbeda. Sebagaimana dikatakan oleh Eliean Hooper-Greenhill (1992: 1), tidaklah benar jika dikatakan bahwa hanya ada satu bentuk realitas bagi sebuah museum, hanya satu modus tetap dalam beroperasi. Berdasarkan perjalanan sejarah museum, realitas museum telah berubah berkali-kali. Museum harus selalu mengubah cara kerja dan apa yang perlu dilakukan sesuai dengan konteks, drama kekuasaan, keterkaitan sosial, ekonomi, dan politik yang mengelilingi museum tersebut. Museum sama dengan semua lembaga sosial lainnya, melayani banyak penguasa dan harus memainkan peran yang sesuai dengan selera penguasa. Bertolak dari pendapat Hooper-Greenhill ini, tampak sekali bahwa peran penguasa terkait erat dengan pengelolaan kedua museum tersebut. Tampaknya penguasa hanya setengah hati memberikan pengamanan kepada kedua museum tersebut sehingga muncul dugaan adanya keterlibatan penguasa atau orang dalam terkait dengan hilangnya sejumlah koleksi pada kedua museum tersebut.

Meskipun keduanya disebut museum, Museum Sonobudoyo di kota Yogyakarta dan Museum Radya Pustaka di kota Surakarta merupakan dua museum yang berbeda secara kultural karena banyak anggota masyarakat yang tinggal di dalam Kraton Yogyakarta dan Kraton Surakarta yang masih percaya bahwa sejumlah benda pada kedua museum tersebut memiliki kekuatan magis. Sebetulnya kepercayaan tentang hadirnya kekuatan magis pada benda-benda koleksi museum juga memainkan peran dominan di Eropa pada abad 15, terutama di Italia. Benda-benda dan artefak-artefak tertentu dianggap hidup dan harus dirawat supaya tidak mati. Bangunanbangunan dan artifak-artifak tersebut juga dipercaya bisa melindungi pemiliknya dari keadaan-keadaan yang tidak menyenangkan. Lebih menarik lagi batu-batu permata tertentu dianggap bisa membuat pemakainya tidak kelihatan, sesuatu yang sulit dimengerti pada masa sekarang di Barat (Hooper-Greenhill, 1992: 66). Pada abad 16 keadaan ini masih bertahan, kekuatan magis dan pengetahuan dianggap satu level kedudukannya (Foucault, 
1970: 32). Pada abad 17, kepercayaan pada kekuatan magis di Eropa mulai berkurang. Dalam konteks kedua museum tersebut, ada kemungkinan bahwa hilangnya sejumlah benda tersebut disebabkan karena adanya upaya untuk menjual benda-benda tersebut dengan harga tinggi kepada pembeli yang juga percaya bahwa benda-benda tersebut memiliki kekuatan magis.

Penelitian ini dilakukan untuk menjawab dua masalah: (1) Aspek-aspek apa yang digarap dalam proses tata kelola ruang Museum Sonobudoyo Yogyakarta dan ruang Museum Radya Pustaka Surakarta?, (2) Apa persamaan dan perbedaan proses tata kelola ruang Museum Sonobudoyo Yogyakarta dan Museum Radya Pustaka Surakarta? Metode penelitian yang digunakan dalam penelitian ini adalah metode komparatif. Metode komparatif bertujuan membandingkan dua subjek penelitian dalam rangka memperlihatkan persamaan dan perbedaan di antara keduanya. Oleh karena itu kurang bernilai jika keduanya sama atau sangat berbeda. Dengan kata lain, metode ini akan memberikan hasil yang baik jika kedua subjek yang diteliti memiliki persamaan sekaligus perbedaan karakteristik (Walker, 1989: 103). Museum Sonobudoyo di Yogyakarta dan Museum Radya Pustaka di Surakarta adalah dua subjek penelitian setara yang memiliki persamaan dan sekaligus perbedaan dan berdasarkan pertimbangan pemikiran yang telah dilakukan, keduanya layak dibandingkan.

\section{Museum Sonobudoyo Yogyakarta}

Museum Sonobudoyo (Gambar.1) didirikan dengan diawali dari keberadaan Java Institute. Java Institute adalah sebuah organisasi yang beranggotakan orang-orang Eropa yang memiliki antusiasme terhadap kebudayaan Jawa. Berbagai koleksi dari berbagai wilayah di Jawa, Madura, Bali dan Lombok akhirnya diserahkan pada seorang Belanda bernama Th. Karsten yang selanjutnya memprakarsai pendirian museum ini. Pada 6 November 1935, Museum Sonobudoyo yang menempati sebuah bangunan bekas kantor diresmikan oleh Sri Sultan Hamengku Buwono VIII.

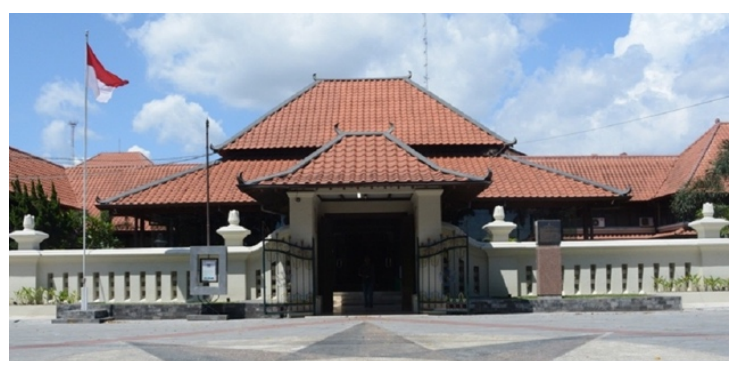

Gambar 1. Museum Sonobudoyo (Sumber: www.sonobudoyo.com)

Museum Sonobudoyo dibuka secara resmi oleh Sri Sultan Hamengku Buwono VIII pada tanggal 6 Nopember 1935 dengan sengkalan "Kayu Winayang Ing Brahmana Budha" yakni tahun 1866 Jawa. Museum Sonobudoyo (Gambar 1) beralamat di Jalan Trikora No. 6, tepatnya di pojok barat laut Alun-alun Utara Yogyakarta. Museum Sonobudoyo dikelola oleh Dinas Kebudayaan Provinsi Daerah Istimewa Yogyakarta. Museum ini mempunyai koleksi benda-benda budaya yang cukup lengkap. Ada perbedaan pendapat menyangkut jumlah pasti yang dimiliki oleh museum ini. Ada data di internet yang menyebutkan bahwa museum ini memiliki koleksi sebanyak 42.698 benda. Dari wawancara dengan petugas museum yang dilakukan oleh peneliti (Jumat 20 Januari 2017) diperoleh keterangan bahwa jumlah koleksi museum adalah 65 ribu benda dan yang dipamerkan adalah sejumlah 27 ribu benda.

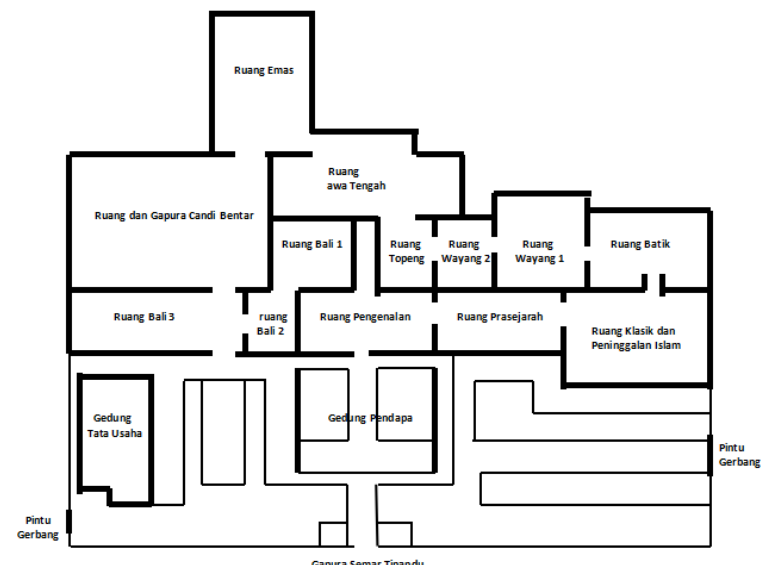

Gambar 2. Pembagian ruang pada Museum Sonobudoyo Yogyakarta 
(Sumber: www.sonobudoyo.com)

Begitu melewati pintu gerbang dan masuk ke halaman dalam museum, pengunjung akan melihat sejumlah arca batu dipamerkan berjajar memanjang mengikuti arah dinding dalam pintu gerbang dan dinding luar museum. Arca-arca ini berasal dari peninggalan zaman Hindu-Budha sejalan dengan masa pembangunan candi-candi Hindu-Budha di wilayah Daerah Istimewa Yogyakarta (DIY) dan Jawa Tengah.

\section{Ruang Pendapa}

Ruang pendapa ini berupa sebuah bangunan tradisional Jawa gaya limasan, dengan ciri utama empt sisi atap miring, dibuat dari bahan kayu jati. Bangunan ini terbuka empat sisinya tanpa dinding sehingga terkesan luas. Interior bangunan diisi dengan seperangkat lengkap gamelan dengan nuansa warna putih. Pengunjung museum yang akan memasuki museum harus melewati ruang ini dan membeli tiket di bagian depan ruang. Sejumlah pemandu museum berseragam batik biasanya berkumpul di ruang ini untuk selanjutnya memandu tamu yang akan berkeliling di museum.

\section{Ruang Pengenalan}

Ruang ini dirancang dengan tujuan untuk mengenalkan kepada pengunjung ringkasan tema-tema pameran dalam Museum Sonobudoyo sesuai dengan urutan ruang agar pengunjung lebih mudah memahami bendabenda yang dipamerkan di dalam museum. Adapun urutan ruang yang ada di museum ini setelah Ruang Pengenalan adalah Ruang Prasejarah, Ruang Klasik dan Peninggalan Islam, Ruang Batik, Ruang Wayang 1, Ruang Wayang 2, Ruang Topeng, Ruang Emas, Ruang Bali 1, Ruang Bali 2, Ruang Bali 1, Ruang Bali 2, Ruang Bali 3.

\section{Ruang Prasejarah}

Ruang Prasejarah digunakan untuk memamerkan berbagai macam benda yangterkait dengan zaman Prasejarah di Indonesia. Benda-benda yang dipamerkan sebagian besar adalah benda asli dan sebagian kecil lainnya adalah benda-benda tiruan. Benda-benda asli berupa moko (genderang perunggu), kapak batu, panah, dan lain-lain. Adapun benda-benda tiruan adalah kerangka kuno manusia (bukan kerangka manusia purba) dan replika tengkorak manusia purba seperti yang dapat dilihat di Museum Trinil. Selain itu di dalam beberapa vitrin (lemari pajang) juga dipasang beberapa tempelan berisi tulisan dan gambar untuk memperjelas latar belakang historis benda-benda prasejarah yang dipamerkan.

\section{Ruang Klasik dan Peninggalan Islam}

Ruang Klasik dan Peninggalan Islam memamerkan benda-benda yang berasal dari zaman klasik Hindu-Budha hingga zaman berkembangnya pengaruh Islam. Sebetulnya kedua zaman ini berlangsung sangat panjang, lebih dari seribu tahun, tetapi pameran bendabenda bersejarah ini memang tidak mewakili kronologi kedua zaman tersebut. Adapun benda-benda yang dipamerkan antara lain prasasti batu bertulis, uang kuno, patung batu, relief batu, alat makan-minum, dan lain-lain (zaman Hindu-Budha); kaligrafi, Kitab Suci Al Quran tulisan tangan dengan hiasan berwarna, senjata, alat untuk pertunjukan wayang, tandu untuk membawa seorang raja atau anggota keluarga raja, dan lain-lain (zaman Islam). Perlu dijelaskan di sini bahwa benda seperti wayang, batik, dan keris juga dihasilkan pada zaman Islam, tetapi benda-benda ini dipamerkan pada ruang-ruang tersendiri. Pada zaman Hindu-Budha dan zaman Islam ternyata juga meninggalkan benda-benda berupa uang logam dengan desainnya yang berbeda dengan desain uang logam dari Cina yang disebut kepeng.

\section{Ruang Batik}

Batik adalah bentuk seni rupa yang sangat populer di Indonesia, terutama di Pulau Jawa. Ruang ini memamerkan berbagai peralatan membatik dan beberapa contoh kain batik yang berkembang di wilayah Yogyakarta. Sebetulnya agak aneh juga bahwa batik diberi 
ruang tersendiri sementara benda-benda dari zaman Hindu-Budha dan zaman Islam, yang mewakili masa panjang lebih dari seribu tahun hanya ditempatkan dalam satu ruangan. Pengadaan ruang khusus untuk batik dimaksudkan untuk mengenalkan kepada pengunjung kekhasan batik Yogyakarta.

\section{Ruang Wayang}

Di dalam Museum Sonobudoyo terdapat dua ruang untuk wayang, letaknya bersambungan. Ruang-ruang tersebut dinamai Ruang Wayang 1 dan Ruang wayang 2. Ada beberapa jenis wayang yang dipamerkan di dalam dua ruang ini tetapi yang paling memakan tempat adalah koleksi seperangkat lengkap wayang kulit gaya Yogyakarta. Koleksi ini memakan ruangan karena memang seluruh tokoh wayang dalam cerita Mahabarata yang diwakili oleh Kerajaan Pandawa dan Astina dihadirkan di sini. Wayang-wayang tersebt dipajang di dalam vitrin memanjang dan pada bagian tengahnya terdapat bentuk wayang gunungan atau kayon. Jenis wayang lain yang dipamerkan di dalam ruang wayang adalah wayang Gedhog, wayang wali, wayang Dupara, wayang Kancil, dan wayang Bali.

\section{Ruang Topeng}

Topeng adalah bentuk seni rupa yang sudah lama dikembangkan di berbagai tempat di Indonesia. Topeng digunakan sebagai penutup wajah untuk menampilkan ekspresi wajah baru. Wajah pada topeng antara lain adalah sedih, gembira, marah, tersenyum, tertawa, dan lain-lain. Topeng digunakan dalam seni pertunjukan seperti seni tari, pantomim, ketoprak, dan lain-lain. Secara umum topeng Yogyakarta diberi warna karena lebih bisa disesuaikan dengan ekspresi wajah yang ingin ditampilkan. Banyak topeng yang dikerjakan dengan sangat halus dan artistik di Yogyakarta karena di daerah ini terdapat banyak perajin yang memiliki keterampilan tinggi. Dalam pentas seni pertunjukan di Yogyakarta, topeng misalnya digunakan delam pertunjukan wayang orang dan dalam sendratari Ramayana yang diselenggarakan di panggung Ramayana Candi Prambanan. Dalam ruang ini ditapilkan beberapa jenis topeng yang dikembangkan di Yogyakarta.

\section{Ruang Jawa Tengah}

Sebetulnya pemberian nama Ruang Jawa Tengah pada ruang ini tidaklah tepat karena wilayah Jawa Tengah adalah luas, juga menyangkut Surakarta, kota di mana Museum Radya Pustaka terletak, sementara ruang ini lebih menonjolkan benda-benda yang berasal dari wilayah Jepara. Nuansa Jepara pada ruang ini sangat menonjol dengan ciri utamanya adalah ukiran kayu yang diterapkan pada kombinasi pintu dan jendela membentuk dinding yang disebut gebyok, dan berbagai benda furnitur.

\section{Ruang Emas}

Ruang ini disebut Ruang Emas karena sebagian benda yang dipamerkan semula memang dibuat dari emas. Tetapi sejak terjadi pencurian beberapa benda emas di museum Sonobudoyo pada tahun 2010, maka sejumlah benda emas yang masih dimiliki oleh museum ini kemudian tidak dipamerkan di museum. Sebagai gantinya, replika dari benda emas tersebut dibuat dengan bahan perak yang lebih murah harganya. Replika ini antara lain berupa tiruan dari topeng emas Nayan yang dibuat dari bahan perak. Selain topeng, beberapa benda dipamerkan di dalam ruang ini seperti kendi logam besar dan sejumlah benda dari bahan kuningan. Sebetulnya vitrin-vitrin di dalam ruang ini dilindungi dengan penutup kaca yang kuat, tetapi kenapa beberapa benda emas bisa diciru masih merupakan tandatanya.

\section{Ruang Bali}

Ruang Bali berisi berbagai macam benda-benda seni rupa bergaya Bali seperti patung. wayang, pintu berukir, dan lain-lain. Benda-benda ini menampilkan gaya khas Bali dengan aneka ragam ukiran dan warna (merah, putih, hitam, warna emas). Budaya Bali ditampilkan agak lengkap di Museum Sonobudoyo seperti tampak pada kehadiran 
area Bali yang disertai pintu gerbang Candi Bentar di halaman belakang dekat Ruang Emas.

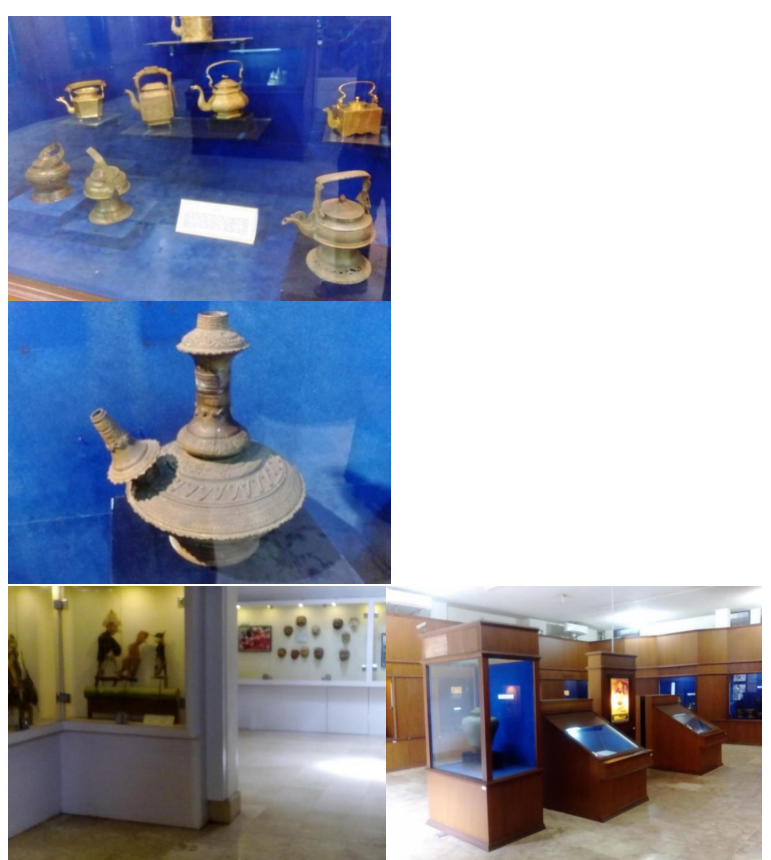

Gambar 3 (dari atas ke arah jarum jam): tempat minum dari perunggu; kendi perunggu; ruang wayang tembus ke arah ruang topeng; dan ruang koleksi benda dari emas (sejak ada pencurian beberapa benda emas tahun 2010, sekarang yang dipamerkan hanya benda-benda tiruan)

\section{Museum Radya Pustaka Surakarta}

Museum Radya Pustaka (Gambar 4) didirikan pada masa pemerintahan Pakubuwono IX oleh Kanjeng Raden Adipati Sosrodiningrat IV di dalem Kepatihan pada tanggal 28 Oktober 1890. Kanjeng Raden Adipati Sosrodiningrat IV pernah menjabat sebagai Patih Pakubuwono IX dan Pakubuwono X. Museum ini lalu dipindahkan ke lokasinya sekarang ini, Gedung Museum Radyapustaka di Jalan Slamet Riyadi, Surakarta, pada 1 Januari 1913. Kala itu gedung museum merupakan rumah kediaman seorang warga Belanda bernama Johannes Busselaar.

Museum Radya Pustaka tidak berada di bawah naungan Dinas Purbakala maupun Dinas Pariwisata Pemerintahan Daerah setempat namun berstatus yayasan. Yayasan ini bernama Yayasan Paheman Radyapustaka Surakarta dan dibentuk pada tahun 1951. Lalu untuk tugas pelaksanaan sehari-hari dibentuk presidium yang pertama kalinya pada tahun 1966 diketuai oleh Go Tik Swan atau juga dikenal dengan nama K.R.T. Hardjonagoro.

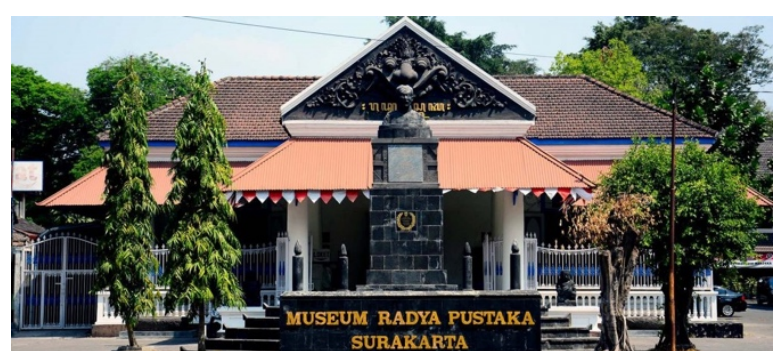

Gambar 4. Museum Radya Pustaka Surakarta (Sumber: www.museum radya pustaka.com)

Pada halaman depan museum, para pengunjung akan menjumpai sebuah patung R. Ng. Rangga Warsita, seorang pujangga keraton Surakarta yang sangat termashur dan hidup pada abad ke-19. Museum Radya Pustaka memiliki koleksi yang terdiri dari berbagai macam arca, pusaka adat, wayang kulit dan buku-buku kuno. Koleksi buku kuna yang banyak dicari itu di antaranya adalah tentang Wulang Reh karangan Pakubuwono IV yang isinya antara lain mengenai petunjuk pemerintahan dan Serat Rama karangan Yasadipura I yang menceritakan tentang wiracarita Ramayana. 


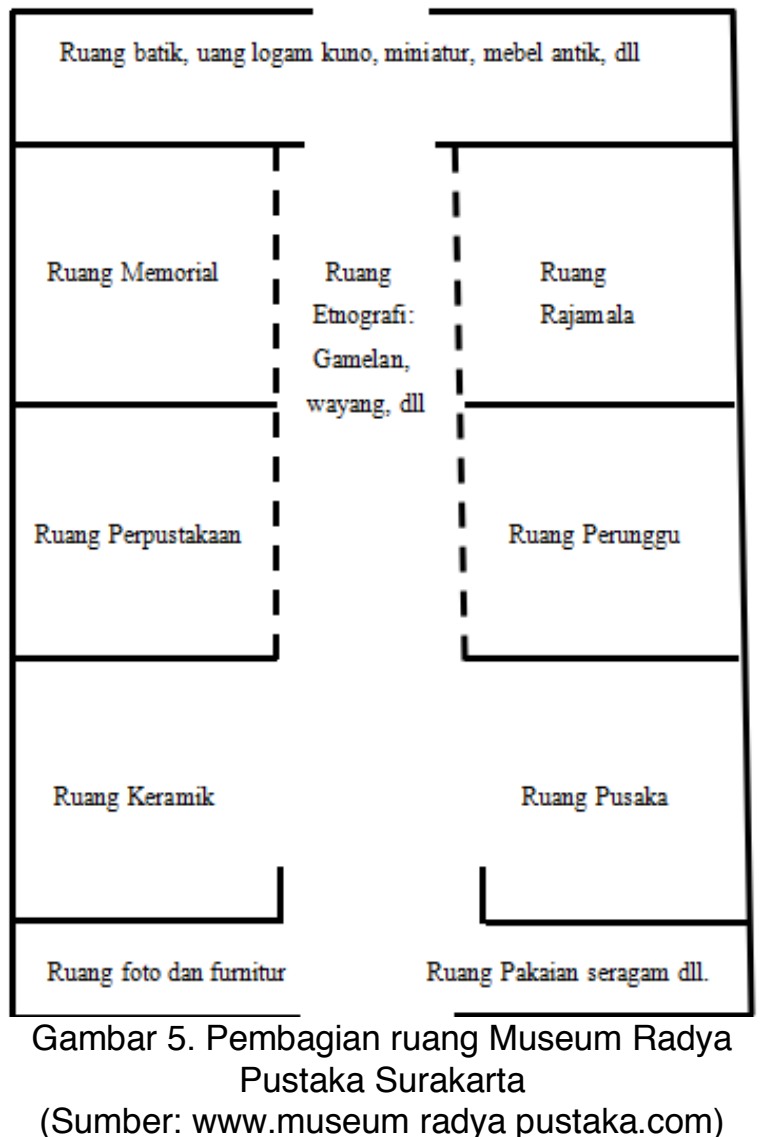

\section{Ruang Teras/Tiket}

Pada ruang teras terdapat tempat pembelian tiket masuk dan ada beberapa meriam beroda dari masa VOC yang berasal dari abad 17 dan 18. Sementara itu ada pula beberapa meriam-meriam kecil milik Keraton Kartasura. Pintu masuk menuju ke dalam museum berjumlah dua dengan komposisi simetris, berwarna biru. Masing-masing pintu memiliki dua daun pintu. Lantai dibuat dengan bahan tegel zaman dulu yang sekarang terkesan kusam. Dinding depan dicat putih tetapi beberapa bagian dari kulit dinding dibiarkan mengelupas sehingga terkesan kotor.

\section{Ruang Pakaian Seragam Keraton dan Ruang Foto/Furnitur}

Begitu pengunjung menginjakkan kaki ke dalam museum, dua ruang pertama yang dijumpai adalah ruang pakaian seragam, topi, dan berbagai lencana zaman dulu di sebelah kanan dan ruang foto-foto dan furnitur kuno di sebelah kiri. Adapun pandangan ke tengah akan tertuju pada patung pendiri museum yang telah dijelaskan sebelumnya dan ruang senjata pusaka di sebelah kanan. Ruang foto dan furnitur terletak di sisi timur berlawanan dengan Ruang Seragam Keraton.

\section{Ruang Keramik}

Ruangan pada sisi sebelah kiri ini disebut sebagai ruang keramik karena secara umum memuat koleksi keramik, porselen, dan gelas-gelas, meskipun ada juga beberapa benda dari bahan kuningan. Ada juga almari panjang yang diisi berbagai koleksi keris, pedang, dan tombak. Sedangkan sisi kanan disebut sebagai ruang senjata/pusaka. Koleksi berbagai jenis piring juga ditampilkan di dalam ruang ini. Piring-piring ini umumnya dibuat dari bahan keramik berkualitas tinggi dengan berbagai hiasannya. Koleksi lain yang dipamerkan di sini adalah berbagai macam benda yang dibuat dari bahan gelas seperti gelas anggur, tempat buah, dan tempat makanan berkuah.

\section{Ruang Senjata/Pusaka}

Ruang ini digunakan untuk menyimpan senjata/pusaka atau biasa disebut tosan aji yang berupa keris, belati, mata tombak dan bermacam-macam pedang antara lain milik Sunan Amangkurat III/Kartosuro dan gada besi milik Keraton Surakarta. Vitrin yang berisi senapan kuno, miniatur meriam, dan topeng juga dipamerkan di area ini.

\section{Ruang Perpustakaan}

Arti nama museum ini sesungguhnya menunjuk pada perpustakaan, bukan museum, karena kalau ditilik artinya kata 'radya' berarti negara atau keraton dan 'pustaka' berarti perpustakaan. Perpustakaan ini sebagian besar koleksinya terdiri dari buku-buku dalam tulisan Jawa. Buku-buku tersebut berisi tentang pengetahuan dan kebudayaan terutama tentang sejarah, budaya, kesenian, ramalan hidup (pakuwon), dan lain-lain.

\section{Ruang Koleksi Benda Perunggu}

Ruang ini berisi koleksi benda perunggu. Ruangan ini menyimpan arca-arca maupun bentuk benda-benda lain seperti 
genta, tempat dupa (padupan), cermin, dan sebagainya. Jumlah karya yang dipamerkan cukup banyak dan ini termasuk koleksi yang lengkap. Ruang ini terletak di seberang ruang perpustakaan dan memamerkan berbagai benda dan arca perunggu berukuran kecil yang dibuat pada masa lalu.

\section{Ruang Memorial}

Pajangan di ruang ini ditujukan untuk mengenang raja-raja yang pernah berkuasa di Keraton Surakarta. Ruang ini dulu digunakan sebagai kantor Panembahan Hadiwidjojo, seorang bangsawan Keraton Surakarta. Pada bagian interior ruang ini dipajang beberapa benda seperti foto raja-raja Keraton Surakarta, vas, meja tulis, dan alat tulis. Pintu masuk ruang ini diberi rantai besi untuk menghalangi pengunjung museum masuk ke dalamnya, tetapi sesungguhnya ada tujuan lain yaitu untuk memberi kesan magis pada ruang tersebut.

\section{Ruang Etnografika}

Ruang ini disebut ruang etnografika, karena terdapat berbagai macam koleksi gamelan peninggalan Keraton Surakarta, wayang, tandu, dan lain-lain. Ruang etnografika menyajikan dua perangkat gamelan dengan laras slendro dan pelog, terdapat juga tandu untuk sesaji, jodang (alat angkut yang dipikul manusia), mesin jam panggung Kartosuro, bermacam-macam kuluk/blangkon untuk kepala, dan berbagai alat rumah tangga. Di sekitar ruang ini juga dipamerkan koleksi beberapa jenis wayang dan seperangkat gamelan dan gong, dan sebuah ruang memorial yang khusus memamerkan lukisan raja-raja Surakarta dari Sunan Pakubuwono IX sampai dengan Pakubuwono ke XII, beberapa alat pabrik dari masa lalu, guci, vas kuno, dan lain-lain,

\section{Ruang Patung Kepala Rajamala}

Ruang ini khusus memajang sebuah patung kepala berukuran besar dinamai Kyai Rajamala, sebuah patung kepala raksasa yang telah berusia lebih dari dua ratus tahun yang terbuat dari kayu jati yang diambil secara khusus dari hutan Donoloyo Wonogiri

\section{Ruang Batik, Uang Logam Kuno, Miniatur, Mebel Antik, d.l.1.}

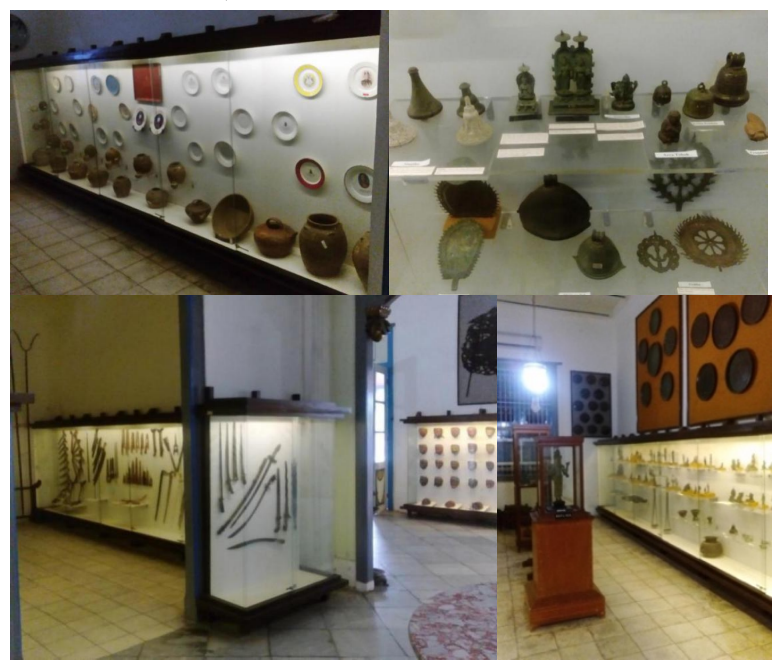

Gambar 6 Contoh-contoh koleksi senjata, benda-benda kuno

dan suasana ruang pajang pada Museum Radya Pustaka.

(Sumber: museum radya pustaka.com)

Ruang terakhir di dalam Museum Radya Pustaka memamerkan berbagai benda koleksi antara lain batik, uang logam kuno dari Jawa dan Cina, gambar-gambar horoskop Jawa (pawukon), mebel antik, miniatur makam rajaraja Yogyakarta dan Surakarta di Imogiri Yogyakarta, dan ruang khusus untuk peringatan (memorial) bagi sastrawan Jawa terkenal, yaitu Ronggowarsito.

\section{Perbandingan Tata Kelola Ruang}

Aspek-aspek yang dilibatkan dalam studi perbandingan ini menyangkut tata kelola museum, tata kelola koleksi, tata kelola staf museum, tata kelola inventaris dan dokumentasi, tata kelola perawatan dan pemeliharaan koleksi, tata kelola pajangan koleksi dan pameran, tata kelola pengunjung, tata kelola keamanan dan kesiapan terhadap bencana. Aspek-aspek ini mengacu pada panduan museum menurut UNESCO (2004).

\section{Perbandingan Tata Kelola Museum}

Mewujudkan sebuah museum yang baik membutuhkan pengelolaan yang efektif. Menurut Edson, dalam konteks panduan 
pengeolaan museum yang digariskan oleh UNESCO, manajemen museum yang efektif merupakan tanggung jawab yang mencakup semua sumber daya dan kegiatan museum dan melibatkan semua staf. Tanpa pengelolaan yang tepat, sebuah museum tidak dapat merawat dan memanfaatkan koleksi dengan baik di samping juga tidak dapat mempertahankan dan mendukung program pameran dan pendidikan yang efektif. Kepentingan dan kepercayaan publik bisa hilang tanpa manajemen yang berkualitas (2004: 134).

Museum Sonobudoyo Yogyakarta dan Museum Radya Pustaka Surakarta samasama belum mampu memilih personil yang tepat untuk menangani pekerjaan yang ada karena keterbatasan dana yang diberikan oleh pemerintah. Hampir semua personil tidak memiliki latar belakang pendidikan kemuseuman dan tidak semuanya pegawai tetap padahal jumlah personil pada kedua museum tersebut terbatas. Akibatnya penentuan jenis pekerjaan, cara kerja yang harus dilakukan, dan pengelolaan hubungan antara personil dan elemen museum yang lain dilakukan kurang profesional.

Meskipun kedua museum tersebut sama-sama belum mampu memilih personil yang tepat karena keterbatasan dana, Museum Sonobudoyo Yogyakarta memiliki personil yang jumlahnya lebih banyak, menerapkan pembagian kerja yang lebih baik, dan mengelola hubungan antara personil dan elemen-elemen museum yang lebih terorganisasi dibandingkan dengan Museum Radya Pustaka Surakarta. Kerja tim personil Museum Sonobudoyo Yogyakarta lebih baik daripada kerja tim personil Museum Radya Pustaka Surakarta, apalagi sekarang ini Museum Radya Pustaka dikelola secara darurat pasca terjadinya pencurian beberapa koleksi dan penutupan museum selama satu tahun karena kekurangan dana. Keprihatinan terhadap situasi darurat pengelolaan Museum Radya Pustaka tampak pada penerimaan pengunjung yang dilayani oleh orang-orang yang tidak mengenakan pakaian seragam sehingga penampilannya tidak bisa dibedakan dari penampilan pengunjung. Selain itu, karena kekurangan personil, pengunjung melihat-lihat koleksi tanpa dikawal oleh pemandu. Hal ini berbeda dengan situasi di Museum Sonobudoyo di mana semua personil mengenakan seragam batik dan pengunjung melihat-lihat koleksi disertai oleh pemandu museum yang akan memberikan informasi tentang bendaa-benda yang dipajang.

Keterbukaan dan rasa saling menghormati merupakan ciri khas tata kelola yang baik, dan ini harus dimulai dari pimpinan museum sendiri. Pada kasus yang menimpa Museum Radya Pustaka, pimpinan museum ternyata tidak bisa dipercaya dalam menjaga keamanan koleksi museum dan justru bekerja sama dengan oknum dari luar museum untuk mencuri beberapa benda museum. Pada kasus pencurian benda-benda emas di Museum Sonobudoyo, pimpinan museum kurang teliti dalam mengontrol faktor keamanan bangunan dan interior museum. Patut disesalkan bahwa CCTV pada kedua museum tidak berfungsi pada waktu terjadi pencurian sebagian koleksi.

\section{Perbandingan Tata Kelola Koleksi}

Manajemen koleksi sangat penting dalam sebuah museum karena sekecil apapun sebuah museum pasti memiliki koleksi dalam jumlah yang tidak sedikit. Dalam konteks panduan museum menurut UNESCO, sebagaimana dikatakan oleh Ladkin, semua museum memiliki karakteristik serupa meskipun mungkin sangat berbeda satu sama lain dalam konten. Museum berisi sejumlah besar benda individual, dokumen, dan artefak yang semuanya mewakili warisan alam, budaya, atau ilmiah. Tata kelola koleksi mengandung arti bagaimana koleksi museum disusun, diteliti, ditafsirkan, dan dipelihara (Ladkin, 2004: 17). Museum Sonobudoyo dan Museum Radya Pustaka memiliki koleksi ribuan benda seperti karya-karya seni rupa, desain, naskah-naskah, mata uang, senjata, pakaian, batik, dan lain-lain. Karena keterbatasan dana dan keahlian permuseuman, dua museum tersebut dikelola secara kurang 
efektif. Meskipun dua museum tersebut masih lemah dalam profesionalitas, tata kelola koleksi Museum Sonobudoyo masih lebih baik dibandingkan dengan Museum Radya Pustaka. Pencurian benda koleksi lebih sering terjadi di Museum Radya Pustaka dibandingkan dengan pencurian yang terjadi di Museum Sonobudoyo.

\section{Perbandingan Tata Kelola staf Museum}

Keberadaan karyawan museum, baik staf tetap atau relawan adalah aset paling vital dari lembaga tersebut (Boylan, 2004: 147). Pendapat ini bisa dimengerti dengan mudah karena tanpa manusia yang bekerja di dalamnya sebuah museum akan menjadi sebuah bangunan mati. Keadaan ini berlaku pada sebuah museum yang bangkrut tidak dikelola lagi atau museum yang jadwal bukanya tidak menentu atau tidak difungsikan selama beberapa waktu tertentu karena kekurangan dana. Kasus semacam ini beberapa waktu lalu pernah menimpa Museum Radya Pustaka dan tidak terjadi di Museum Sonobudoyo. Sekitar setahun Museum Radya Pustaka ditutup untuk beberapa bulan karena pengelolaannya tidak efektif pasca terjadinya pencurian benda koleksi.

\section{Perbandingan Tata Kelola Inventaris dan Dokumentasi}

Museum-museum yang profesional sangat mementingkan pendokumentasian benda-benda koleksi museum secara akurat. Benda-benda koleksi museum bisa berstatus koleksi permanen atau pinjaman. Pencatatan secara legal benda-benda tersebut sejak awal diakuisisi atau dipinjam tentulah sangat penting. Hal ini mempermudah dilakukannya katalogisasi masing-masing benda untuk mempermudah pencarian ketika benda-benda tersebut disimpan dan ketika benda-benda tersebut ditanyakan oleh pengunjung atau peneliti yang bermaksud mempelajari bendabenda tersebut lebih jauh. Dalam sebuah museum yang profesional, akuisisi sebuah benda untuk museum juga harus disertai surat pernyataan transfer kepemilikan benda tersebut (.Roberts, 2004: 31)

Dari puluhan ribu benda koleksi yang dimiliki oleh Museum Sonobudoyo dan Museum Radya Pustaka, sebagian besar benda koleksi tidak memiliki surat bukti akuisisi secara legal meskipun benda-benda tersebut memang diperoleh lewat jalan yang benar. Karena banyak benda-benda koleksi yang dipajang di dua museum tersebut adalah berasal dari Keraton Yogyakarta dan Keraton Surakarta, maka proses akuisisinya kebanyakan hanya dicatat di buku catatan milik museum, tidak satu-persatu disertai surat transfer kepemilikan yang legal, meskipun setiap benda diberi label, nomor, tanda, dan juga dicatat dalam sistem manual dan sistem berbasis computer. Oleh karen itu informasi tentang benda-benda yang dicuri di dua museum tersebut beberapa tahun lalu disampaikan ke publik tidak disertai data akuisisi yang legal dan mendetail.

\section{Perbandingan Tata Kelola Perawatan dan Pemeliharaan Koleksi}

Di negara maju sebuah museum cenderung diupayakan untuk berkembang dengan menambah jumlah koleksi, baik dengan membeli atau menerima sumbangan. Pada sisi lain koleksi museum juga semakin tua umurnya (Michalski, 2004: 51). Koleksi yang dimiliki oleh Museum Sonobudoyo dan Museum Radya Pustaka juga semakin tua umurnya, tetapi jumlah koleksi hampir tidak berkembang karena jarang menerima sumbangan dan tidak memiliki dana untuk membeli benda baru.

Persoalan lain yang dihadapi kedua museum adalah penanganan kebakaran. Andaikata terjadi kebakaran, terutama di malam hari, dua museum tersebut akan kesulitan menghadapinya. Memang bangunan dua museum itu kuat, tetapi dalam kondisi terjadi kebakaran justru penyelamatan bendabenda koleksi itu yang paling sulit. Banyak benda koleksi berharga pada dua museum itu yang dibuat dari bahan mudah terbakar seperti kayu yang berukuran besar yang tentu saja 
butuh waktu dan tenaga untuk menyelamatkan. Sulitnya penyelamatan ini juga disebabkan karena setiap ruang pada dua museum tersebut diisi dengan benda-benda dengan posisi berdesakan karena keterbatasan ruang. Tata kelola ruang pada Museum Sonobudoyo lebih bagus daripada Museum Radya Pustaka karena sejumlah benda koleksi dari bahan berharga, misalnya bahan emas, hanya diwakili oleh tiruannya dalam pajangan. Museum Sonobudoyo juga lebih diuntungkan dengan keberadaan ruang terbuka di sisi depan, samping kiri, dan sisi samping kanan museum sehingga ketika terjadi kebakaran pengeluaran benda-benda koleksi yang sensitif terhadap kebakaran lebih cepat dilakukan. Sementara itu Museum Radya Pustaka hanya memiliki satu alternatif ruang terbuka yaitu di sisi depan, sehingga apabila terjadi kebakaran sisi depan akan menjadi satu-satunya jalur penyelamatan.

Dua museum tersebut juga menghadapi masalah kelembaban, serangga, cahaya, dan polusi yang tidak mungkin ditangani sepenuhnya karena keterbatasan dana dan status bangunan yang digunakan sebagai bangunan lama yang memang semula tidak didesain untuk museum. Menyangkut pencahayaan ruangan museum misalnya, dua museum tersebut tidak mungkin secara rutin menjamin bahwa listrik akan menyala terus tanpa gangguan dan semua benda memperoleh jatah penerangan yang sesuai standar yang sudah dipakai sejak lama, misalnya tekstil dan karya di atas kertas harus diterangi cahaya 50 lux dan lukisan serta benda-benda dicat harus diterangi cahaya 150 lux (1 lux adalah terang cahaya yang dihasilkan oleh sebuah lilin yang dipegang tangan). Menurut Michalski, pengunjung berusia lanjut tidak bisa melihat detail benda dengan terang cahaya 50 lux (level terang cahaya yang direkomendasikan untuk tekstil yang sensitif terhadap cahaya, lukisan cat air, dan naskah (Ibid.: 178).

Karena bangunan Museum Sonobudoyo dan bangunan Museum Radya Pustaka adalah bangunan lama yang memiliki banyak jendela, maka sela-sela setiap jendela selalu kemasukan udara yang membawa debu, meskipun lembut. Dalam waktu beberapa hari ruang-ruang interior dua museum itu menjadi kotot dan harus secara rutin dibersihkan. Jumlah debu yang masuk menjadi lebih banyak karena pintu-pintu bagian depan museum juga dibuka, meskipun pembukaan pintu-pintu ini mengurangi penggunaan AC. Pembukaan pintu-pintu dan adanya sela-sela terbuka pada jendela mengakibatkan ruang menjadi lembab, terkena polusi, dan memungkinkan serangga masuk ke dalam ruang interior. Terkait dengan kelembaban, dua museum tersebut tidak menyediakan alat dehumidifier untuk mengurangi kelembaban.

\section{Perbandingan Tata Kelola Pajangan Koleksi dan Pameran}

Kebanyakan orang datang ke museum untuk melihat semua benda yang dipajang dalam satu kali kunjungan; tentu saja hal ini tidak dianjurkan (Herreman, 2004: 94). Kenyataan di banyak museum memang begitu dan bahkan banyak juga pengunjung yang mengelilingi ruang interior museum yang memajang banyak benda dalam waktu yang singkat. Hal ini juga terjadi di Museum Sonobudoyo dan Museum Radya Pustaka. Tata kelola pajangan koleksi dan pameran pada kedua museum ini masih kurang menarik karena tidak disertai proses desain yang matang. Keterbatasan dana merupakan kendala pelibatan proses desain yang matang.

\section{Perbandingan Tata Kelola Pengunjung}

Dalam sebuah museum, baik yang berukuran bear maupun kecil, pelayanan terhadap pengunjung berperan sangat penting. Menurut Woollard, pelayanan yang baik pada pengunjung mengurangi rasa frustasi, ketidaknyamanan, dan kelelahan serta membantu pengunjung menikmati pameran yang diselenggarakan. Tanpa pelayanan yang bagus kepada pengunjung, peluang untuk menikmati dan belajar pada pameran yang diselenggarakan berkurang dan jumlah kunjungan kembali menurun (2004 111). 
Meskipun sama-sama menghadapi masalah keterbatasan dana, pelayanan pada pengunjung yang diberikan oleh Museum Sonobudoyo lebih bagus daripada pelayanan yang diberikan oleh Museum Radya Pustaka. Penelitian ini dilakukan beberapa hari setelah Museum Radya Pustaka dibuka kembali, setelah beberapa bulan ditutup karena terjadinya beberapa kali pencurian benda koleksi. Pelayanan pada pengunjung yang diberikan oleh Museum Radya Pustaka pada saat penelitian ini dilakukan tidak profesional karena ketika pengunjung datang tidak ada kejelasan siapa orang yang akan melayani pengunjung. Pengunjung harus memberitahu kepada beberapa orang yang berdiri atau duduk di situ tentang keinginannya untuk masuk dan melihat benda-benda koleksi. Salah seorang dari mereka kemudian menyodorkan buku tamu untuk diisi. Tidak ada konter pelayanan pengunjung dan ketika berada di dalam museum pengunjung tidak ditemani oleh pemandu. Beberapa petugas museum yang berada di dalam ruang pun tidak mengenakan seragam sehingga penampilannya sulit dibedakan dari pengunjung.

Pelayanan pada pengunjung yang diberikan di Museum Sonobudoyo lebih bagus daripada pelayanan yang diberikan di Museum Radya Pustaka. Pelayanan pada pengunjung yang diberikan di Museum Sonobudoyo pada saat penelitian ini dilakukan lebih profesional karena ketika pengunjung datang ada kejelasan siapa orang yang akan bertugas melayani pengunjung. Mereka berjumlah banyak dan berpakaian seragam batik. Karena disertai oleh pemandu, pengunjung bisa memperoleh banyak informasi tentang benda-benda koleksi, baik yang dipajang maupun yang disimpan di dalam gudang. Ketika jumlah pengunjung banyak pada waktu hari-hari libur memang petugas agak kewalahan melayani mereka, tetapi karena petugas banyak jumlahnya maka keadaan ini masih lebih baik dibandingkan dengan keadaan di Museum Radya Pustaka. Sayangnya informasi yang dimuat dalam katalog yang bisa diperoleh secara gratis di Museum Sonobuoyo juga terbatas seperti di
Museum Radya Pustaka karena katalog tersebut hanya berupa selembar kertas dilipat yang hanya memuat beberapa contoh benda koleksi disertai informasi sekadarnya tentang beberapa benda tersebut. Akibatnya di sini juga sulit bagi pengunjung untuk memperoleh informasi padat tentang benda-benda koleksi di museum ini secara cepat.

\section{Perbandingan Tata Kelola Keamanan dan Kesiapan Terhadap Bencana}

Sebuah museum yang bagus akan berfungsi efektif jika memiliki kesiapan dalam menangani keamanan dan bencana yang mungkin terjadi. Menurut Jirazek, analisis risiko harus memperhitungkan semua bahaya yang dapat merusak koleksi atau museum itu secara signifikan (2004: 182). Mempertimbangkan lokasi Museum Sonobudoyo Yogyakarta dan Museum Radya Pustaka Surakarta, potensi ancaman keamanan dan bencana alam yang mungkin dihadapi oleh dua museum tersebut antara lain adalah sebagai berikut: infiltrasi binatang (serangga, tikus) dan jamur, gempa bumi, kerusakan bangunan, kebakaran, gangguan listrik dan telpon, kontaminasi bahan kimia, kerusakan koleksi, hilangnya kunci, hilangnya data penting, kerusakan perabot dan peralatan interior, masuknya orang secara tidak sah, pencurian/perampokan, vandalism/grafiti, penyalahgunaan alkohol dan penggunaan narkoba di area museum, serangan teroris. Menyadari adanya keterbatasan dana, kedua museum tentu harus bekerja berdasarkan kemampuan yang dimiliki.

\section{Kesimpulan}

Aspek-aspek yang dikaitkan dalam studi perbandingan tata kelola ruang interior ini adalah tata kelola museum, tata kelola koleksi, tata kelola staf museum, tata kelola inventaris dan dokumentasi, tata kelola perawatan dan pemeliharaan koleksi, tata kelola pajangan koleksi dan pameran, tata kelola pengunjung, dan tata kelola keamanan dan kesiapan terhadap bencana. Dalam konteks tata kelola 
museum, tata kelola ruang yang telah dilakukan terhadap dua museum baru terbatas pada penambahan cahaya ruang, pengamanan koleksi, penempatan benda-benda berharga di tempat yang lebih aman dan peningkatan pengawasan dengan menggunakan CCTV. Meskipun begitu tata kelola ruang yang dilakukan oleh Museum Sonobudoyo lebih baik karena mobilisasi pengelola melibatkan karyawan yang lebih banyak dan peningkatan fasilitas untuk berbagai fungsi di dalam museum lebih lengkap.

Tata kelola koleksi yang dilakukan oleh Museum Sonobudoyo masih lebih baik dibandingkan dengan yang dilakukan oleh Museum Radya Pustaka, terutama menyangkut pengamanan koleksi. Sistem perlindungan koleksi d Museum Radya Pustaka agak lemah karena hanya menggunakan gembok kunci sehingga bagi pencuri yang ahli, gembok tersebut mudah dibuka atau dirusak. Hal ini diperparah dengan kenyataan bahwa personil pengamanan koleksi di Museum Radya Pustaka sedikit jumlahnya. Tata kelola staf museum yang dilakukan oleh Museum Sonobudoyo lebih baik dibandingkan dengan Museum Radya Pustaka karena, meskipun pendanaan dua museum tersebut terbatas, dana yang yang dimiliki oleh Museum Sonobudoyo Yogyakarta untuk mengelola personil masih lebih banyak dibandingkan dengan dana yang dimiliki oleh Museum Radya Pustaka.

Tata kelola inventaris dan dokumentasi pada keduanya, Museum Sonobudoyo dan Museum Radya Pustaka, belum bagus karena hanya sebatas revitalisasi ruang yang tersedia agar inventaris dan dokumentasi mudah dkelola. Upaya yang telah dilakukan meliputi pengaturan letak inventaris dan dokumentasi, pengontrolan lewat pengawasan langsung dan penambahan fasilitas computer yang terbatas jumlahnya. Tata kelola perawatan dan pemeliharaan koleki pada kedua museum belum baik,. meskipun begitu apa yang telah dilakukan oleh Museum Sonobudoyo lebih bagus daripada Museum Radya Pustaka karena sejumlah benda koleksi dari bahan berharga, misalnya benda yang dibuat dari bahan emas, hanya diwakili oleh tiruannya dalam pajangan. Museum Sonobudoyo juga lebih diuntungkan dengan keberadaan ruang terbuka di sisi depan, samping kiri, dan sisi samping kanan museum sehingga ketika terjadi kebakaran pengeluaran benda-benda koleksi yang sensitif terhadap kebakaran lebih cepat dilakukan. Sementara itu Museum Radya Pustaka hanya memiliki satu alternatif ruang terbuka yaitu di sisi depan, sehingga apabila terjadi kebakaran sisi depan akan menjadi satu-satunya jalur penyelamatan. Tata kelola pajangan koleksi dan pameran tidak bisa dilakukan secara optimal karena keluasan ruang pada kedua museum terbatas. Oleh karena itu penyelenggaraan pameran tidak tetap yang memamerkan benda-benda koleksi dari luar museum tidak mudah dilakukan. Kendala lain adalah keterbatasan dana dan tiadanya jaminan bahwa benda-benda tersebut tidak akan rusak atau hilang.

Tata kelola pengunjung pada Museum Sonobudoyo lebih baik daripada pelayanan yang diberikan oleh Museum Radya Pustaka. Pelayanan pada pengunjung yang diberikan oleh Museum Sonobudoyo pada saat penelitian ini dilakukan lebih profesional karena ketika pengunjung datang ada kejelasan siapa orang yang akan bertugas melayani pengunjung. Mereka berjumlah banyak dan berpakaian seragam batik. Pengunjung tidak perlu memberitahu kepada petugas tentang keinginannya untuk masuk dan melihat bendabenda koleksi karena begitu pengunjung melewati pintu gerbang masuk langsung menjumpai konter petugas pelayanan pengunjung. Pengunjung langsung diarahkan ke situ untuk menuliskan namanya serta membeli tiket masuk.

Karena disertai oleh pemandu, pengunjung bisa memperoleh banyak informasi tentang benda-benda koleksi, baik yang dipajang maupun yang disimpan di dalam gudang. Ketika jumlah pengunjung banyak pada waktu hari-hari libur memang petugas agak kewalahan melayani mereka, 
tetapi karena petugas banyak jumlahnya maka keadaan ini masih lebih baik dibandingkan dengan keadaan di Museum Radya Pustaka. Sayangnya informasi yang dimuat dalam katalog yang bisa diperoleh secara gratis di Museum Sonobuoyo juga terbatas seperti di Museum Radya Pustaka karena katalog tersebut hanya berupa selembar kertas dilipat yang hanya memuat beberapa contoh benda koleksi disertai informasi sekadarnya tentang beberapa benda tersebut. Akibatnya di sini juga sulit bagi pengunjung untuk memperoleh informasi padat tentang benda-benda koleksi di museum ini secara cepat..

Dengan keterbatasan dana dan ruang yang ada, Museum Sonobudoyo dan Museum Radya Pustaka belum mampu secara efektif melayani semua jenis pengunjung meliputi peneliti, pengajar perguruan tinggi, guru, mahasiswa, siswa, orang cacat atau lemah fisik (termasuk mereka yang penglihatannya kurang bagus sehingga membutuhkan ukuran label tulisan yang lebih besar), lansia, dan anakanak. Untuk bisa mengakoodasi semua jenis pengunjung tersebut memang dibutuhkan dana yang lebih besar, petugas yang lebih banyak, dan ruangan yang lebih luas. Mengingat bahwa pengembangan museum bukanlah prioritas utama dalam pembangunan di Indonesia, upaya mewujudkan efektifitas pengelolaan dua museum tersebut tidak akan terwujud dalam waktu cepat, dengan demikian re-desain ruang interior yang dilakukan selama ini sifatnya hanya lebih memperbaiki kinerja dua museum tersebut, belum sampai ke tingkat efektifitas puncak.

Tata kelola keamanan dan kesiapan terhadap bencana pada kedua museum belum baik. Karena pintu-pintu pada kedua museum dibuka hampir setiap hari, dan juga adanya sela-sela lobang pada jendela-jendela, ancaman infiltrasi binatang (serangga, tikus) tidak terhindarkan. Adapun ancaman jamur hanya bisa ditangani secara manual dan alatnya kurang canggih. Sebagaimana biasa di lingkungan Yogyakarta dan Surakarta, dua museum tersebut bisa mengalami gangguan listrik dan telpon setiap waktu. Ketika listrik mati tiba-tiba yang berasal dari pusat, belum ada generator canggih yang bisa digunakan tanpa menimbulkan bunyi bising. Kerusakn koleksi bisa terjadi sewaktu-waktu karena banyak benda-benda koleksi tua yang dibuat dari bahan yang rapuh seperti naskah kuno sementara temperature ruangan tidak bisa terjaga stabilitasnya, katakanlah dengan terang cahaya 50 lux sepanjang waktu. Vandalism/grafiti juga bisa terjadi sewaktuwaktu dan sejauh ini upaya pencegahannya di dua museum tersebut baik. Sejauh ini ancaman penyalahgunaan alkohol dan penggunaan narkoba di area museum dan masuknya orang secara tidak sah bisa dicegah dengan baik. Tetapi harus diingat bahwa dua museum lemah dalam sistem pengawasan jarak dekat (CCTV/Close Circuit TV) sistem pengendalian akses (ACS/Access Control System) dan sistem pendeteksi penerobos museum (IDS/Intruder Detection Sstem).

\section{Daftar Pustaka}

Roberts, Andrew. (2004). "Inventories and Documentation”, in Patrick J. Boylan (ed.), Running a Museum, a Practical Handbook. Paris: ICOM-UNESCO.

Boylan, Patrick. "Managing People," in Patrick J. Boylan (ed.), Running a Museum, a Practical Handbook. Paris: ICOMUNESCO, 2004.

Edson, Gary. "Museum Management", in Patrick J. Boylan (ed.), Running a Museum, a Practical Handbook. Paris: ICOMUNESCO, 2004.

Foucault, Michel. The Order of Things. London: Tavistock Publications, 1970.

Herreman, Yani. Display, Exhibits and Exhibitions, in Patrick J. Boylan (ed.), Running a Museum, a Practical Handbook. Paris: ICOM-UNESCO, 2004. 
Hooper-Greenhill, Eilean. Museums and the Shaping of Knowledge. London: Routledge, 1992.

Jirazek, Pavel. "Museum Security and Disaster Preparedness", in Patrick J. Boylan (ed.), Running a Museum, a Practical Handbook. Paris: ICOM-UNESCO, 2004.

Ladkin, Nicola. "Collections Management", in Patrick J. Boylan (ed.), Running a Museum, a Practical Handbook. Paris: ICOMUNESCO, 2004.

Michalski, Stefan. "Care and Preservation of Collections", in Patrick J. Boylan (ed.),
Running a Museum, a Practical Handbook. Paris: ICOM-UNESCO, 2004.

Suryono, Alwin. Pelestarian Arsitektur Museum Sonobudoyo Yogyakarta, penelitian tidak dipubluikasikan, Bandung: Universitas Katholik Parahyangan, 2012.

Walker, John A. Design History and the History of Design. London: Pluto Press, 1989.

Woollard, Vicky. "Caring for the Visitors," in Patrick J. Boylan (ed.), Running a Museum, a Practical Handbook. Paris: ICOMUNESCO, 2004. 